\title{
CHAPTER $X$
}

\section{Conclusions}

Democratization is a lengthy, contextualized and often unpredictable process in which elements of democratic regime according to plan or theory articulate with long-established patterns of governance and politics in a specific society. This book described that process in West Sumba over the period 1986-2006. Local leaders in Sumba have used the opportunities created by changes in the national political context in Indonesia in that period and have adapted well to these changes. Consequently, the style of local politics changed, as did the criteria for leadership.

Although 21 May 1998 is now always mentioned as the landmark indicating the start of a new period in history in which Indonesia would be quickly transformed into a democracy, introducing democracy was attempted earlier, and also on Sumba. Onvlee (1973:118) narrated about the first democratic period after independence:

In [...] 1946 I attended a meeting between the representative of the Dutch East Indies government and several West Sumbanese leaders at the government office in Waikabubak. The government representative told the leaders that a new era had started; that a regime was bound to be created based on new principles to achieve administration atas alasan demokrasi, based on democracy. One of the attendants was so wise to ask Apakah itu demokrasi?, what is that democracy? The government representative quickly looked it up in Van Ronkel's dictionary and found: pemerintah rakyat, governance by the people. That did not clarify much, but yet it gave the impression to some of the Sumbanese leaders that their long-cherished wishes with regard to their own territories might come true. In one case it instigated people's action led by a member of the new elite for returning their territory to the domain it belonged to previously.

Just after the demise of the Suharto regime, the same question 'what is democracy' was as relevant, urgent and puzzling as it was in 1946. Just as in the case quoted by Onvlee, in 2003 the opportunities of democratization stimulated a people's movement to shift the boundaries of their territory. In 2003 the new word for this process was pemekaran. That was not the only practical consequence of democratization, but just one type of administrative and political change that has happened in Sumba over the last 20 years. In 
the previous chapters, I described a repertoire of the political strategies of the local leaders: from pragmatically using the opportunities provided by legal pluralism, to resorting to mass-violence, to creating new administrative territories, to competing in democratic elections. Each of these strategies was prominent in one of the phases of recent West Sumbanese political history. The overview of the sequence events allows recognition of continuities in style, and also in the roles of particular individuals. That overview comprises an ethnography of democratization.

\section{The local context}

A democratization process in practice can be regarded as articulation of political cultures. Therefore the first chapters started with historical and cultural aspects of Sumbanese leadership and politics. The history of state formation and intervention by both colonial government and Christian missions led to the conclusion that this particular historical combination created a Christian local elite, with members who were part of Sumbanese nobility and owed part of their status and power to the offices they occupied in service of the colonial government. These same Sumbanese men were the most skilled administrators, who also enjoyed considerable local authority due their traditional status, and therefore they continued to rule after Indonesian Independence and also survived the changes of regime between 1945 and 1998. These leaders lived between a modern world outside Sumba, where their superiors resided, and a more traditional world on Sumba, especially in their home villages, where they ruled but were also part of the family. Janet Hoskins (1993:287) observed that in the late colonial period Sumbanese (in Kodi) made a distinction between their own social and geographic sphere of the ancestral village where they worshipped their spirits, and everything beyond the island and those things pertaining to government offices, hospitals and schools belonging to the realm of the foreigners and the Christian religion. Christianity was seen as an entrance to the wider world, and Sumbanese developed the attitude of combining two religions; the connection between Christianity and education resulted in the fact that the administrative elite of Sumba is and has been Christian.

Many anthropological studies on Sumba analyse the traditional aspects of life, with an emphasis on objects of study that fit well into the Eastern Indonesian studies in which structural anthropology dominated (Forth 1981; Geirnaert-Martin 1992). Sumba is also thought to be one of the places on earth where the researcher can encounter the clearest contrast with cultural phenomena in the western world. Janet Hoskins (1993) used this Sumba-Western world tension to analyse concepts of time and history, Webb Keane (1997) 
used it to develop a theory on representation, Joel Kuipers (1998) to analyse language change in relation to political marginality, and in my own dissertation economic rationality was the object of comparison (Vel 1994). When data about traditional concepts are required, it makes sense to do empirical research in the remotest parts of the rural area. This book focused on the interface between Indonesian national politics and Sumbanese reality, where the main players speak Bahasa Indonesia, are relatively well-educated, have travelled to other areas and are usually proud being both Indonesians and Sumbanese. It is the mixture or articulation of traditional and modern repertoires used in contemporary political practice that makes this book different from most anthropological studies about Eastern Indonesia.

The local context is not just a matter of traditional or changing ideas, but also the influence of more material changes. Many of those 'technical' changes have taken place in the nearly two decades covered in this book, starting with the end of the 1980s until 2006. In the last decade of the New Order, the government executed programmes for improvement of infrastructure that even reached the interiors of Sumba: many roads were built and paved, so that communication and trade with town became easier and more frequent. Public primary schools were built all over the rural area so that each child could get to school within one hour's walk. Since 1995, there have been government programmes to bring electricity to the country side. Along the main road they installed permanent facilities and people living in the interior villages could get subsidized solar panels. Electricity brought television, and since the end of the 1990s many Sumbanese regularly watch television and see what happens in other parts of their country and in the world. In 2005, a teacher in Anakalang asked my opinion about the acts of war of the Israeli against the Palestinians, and such an issue of discussion would have been unimaginable in 1980s, when conversations on Sumba were still very much internally focused. Transport facilities, media and education brought the Sumbanese much closer to the world outside their island, and inserted new languages, new ideas and new points of reference in their lives. This created a very different world from the Sumba described earlier by the studies mentioned above, for which field work was done in the 1980s.

In the twenty-first century, there are many relatively well-educated Sumbanese. The third or fourth generations of the families that were first selected as pupils in the mission's school have now earned their bachelors' degree or gone farther in Kupang or on Java. Sumbanese parents regard education of their children as top investment in their (own) future. They hope education will lead to a regular job with a good salary, preferably a position as civil servant. On Sumba the state is regarded as the best employer. Those who succeed in getting such a position do not stay in their home village. They move to a house close to their office, so many educated people end up 
in town, whereas the permanent inhabitants of villages are the tani (farmers) which is a broad, emic category including everyone without a permanent salaried position. Yet, even when living in town, all Sumbanese maintain a link with their home village, with their Uma, the small group of people that originated from a particular ancestral house. This is the core social group that is responsible for the main human life ceremonies, in particular weddings and funerals. Even the most professionally successful Sumbanese, who live in Java or abroad, still regard their clan-membership as very important part of their identities. Their place in the kinship system defines relations with other Sumbanese, and in turn the type of exchanges that are considered appropriate. Patrilineal clans, kabihu, are exogamous, and relations with other clans are defined as either as bride-giver or bride-receiver, never both. At each ceremonial event, traditionally bride-receivers should bring horses and buffaloes to the bride-givers. Basically, this exchange economy has not changed since the 1980s, but the shape of exchange items is often modernized, especially in town, where the monetary economy is stronger than the barter economy. Nowadays at a wedding in the capital part of the bride dowry can be paid with a kuda Jepang (Japanese horse), a motorcycle.

Another way in which the exchange economy is monetized appears when the father of a bride does not collect the cloth he needs for his daughter's dowry from his own kinsmen, but just buys them in a shop in town. The moral economy of exchange as I described in The Uma economy (Vel 1994) still exists in 2006, but it is modernized and partly monetized. What remained a major continuity of Sumbanese society up to 2006 is the moral obligation of reciprocity. That important characteristic is part of contemporary strategies to accumulate political power.

To my surprise, I found that many of the successful Sumbanese discussed in the chapters of this book had an exit-option to the obligations of the Sumbanese moral economy. They were married with a woman from outside Sumba, and did not marry at home. With that act they party excluded themselves from their own kinship system, because they refrained from reciprocating earlier marriage ties. Economically, this could be a favourable escape from expensive bride-prices, and continuous streams of material contributions to the wife's clan's ceremonies. It could also lead to a degree of detachment to Sumba and more freedom to pursue a successful career outside the island.

\section{Capital and leadership}

The same stories about exchanges and strategies in avoiding or using reciprocal obligations can be understood in terms of accumulation and transformation of various forms of capital. Bourdieu (1986:243) distinguished between 
cultural, economic and social capital. The use of 'capital' is a way of addressing differential resources of power, and of linking an analysis of the cultural to that of the economic. The key theoretical question is how these different forms of capital transform themselves into each other in order to maximize accumulation. In the case of the wealthy father of the bride who bought the dowry cloths in town, dowry becomes economic capital, whereas it used to be transformed into social capital. Sumbanese with a 'foreign' wife have the option to stop investing in social capital and accumulate more economic capital. Sumbanese parents hope that the cultural capital resulting from the education of their children, paid for by their economic capital for years, will be transformed in old age security: a combination of social and economic capital. In the previous chapters I used the notion of accumulation of forms of capital as a way to understand how people in Sumba gain power, and how they manipulate various sources of power to reach their political ends.

The case study in Chapter IV described a power struggle between a village head, who belonged to the local nobility, and the young foreign leader of the development project that worked in the village head's village. Both competitors had accumulated a considerable amount of capital, but in very different ways. There was no conclusion about who was more powerful, who's capital was larger or carried more weight. Both enjoyed power positions in the village, but based on different criteria and addressed at different identities of the village constituency. To win the dispute or power struggle the competitors invented strategies that applied to the normative order in which each of them was superior. Village leaders are actors in the realm of all different normative orders that exist in their village. They are skilled in forum shopping: 'when fields of jurisdiction of different institutions overlap, disputants can choose between these institutions. They base their choice on what they hope the outcome of the dispute will be, however vague and ill-founded their expectations may be' (K. von Benda-Beckmann 1984:37). Questions about preference for a specific normative system or its legitimacy are not so relevant. What matters is how useful the institutions, the networks and the rules and sanctions are for pursuing a particular political goal. Strategic use of hierarchies, networks and rules is a characteristic of Sumbanese politics, starting at village level. This focus on hierarchies is an impediment for women, youth and lower status men from getting involved in politics. Forum shopping is a strategy that is only adoptable by those who have a sufficient amount of capital and therefore access to the different institutions constituting legal pluralism. The consequence for people who lack access is not very favourable. If rights and state services become negotiable and there is no institution or force willing or able to ensure rights and access to state services to all persons, eventually state services or rights will be traded off just like economic or social services. In that case forum shopping requires a 
full purse, and people with an empty purse will return empty-handed.

Another conclusion concerning the link between forms of capital and power in Sumba concerns transformation from one type of capital into another for the purpose of increasing status by using opportunities created by decentralization laws. In Chapter VIII three Sumbanese residing outside Sumba were discussed as main actors behind the movement to create a new district in West Sumba. What these actors had in common is that they were born on Sumba, received a good education and, with or without a church scholarship, pursued their education on Java. Consequently they had a successful career, after which they wanted to return to their home island, where they enjoyed high prestige and status and social security provided by their relatives. They were connected through various modern networks: the political party, student alumni organizations, the Christian Church or the unions of emigrant Sumbanese in cities outside Sumba. In terms of forms of capital, they all had accumulated a considerable amount. Yet, what they lacked was domestic social capital and traditional type of cultural capital. Their 'overseas' capital could be transformed into status and old age security in Sumba, and leading a successful campaign could be a further way to accomplish that.

Pote Leba and doctor Nelis, the candidate pair described in Chapter IX that won the elections, jointly had a large amount of capital. The victory of this pair supports the argument that not just the quantity of capital is decisive in winning elections, but the balance of different types of capital. In Sumba, the results of the pilkada elections show that wealth as economic capital is not sufficient to win and thus the bupati positions are not for sale. Wealth in terms of traditional cultural capital such as attributes of the traditional aristocracy, is still an asset in election campaigns, but it is not sufficient for election victories.

\section{Political identity}

Since the independence of Indonesia until 1995, all bupati in West Sumba were sons of former raja. During the New Order they were appointed by the Minister of Home Affairs. As Umbu Djima's biography in Chapter II showed, the Governor considered it better that a Sumbanese be the bupati on Sumba, but the competition over these offices was between the Military and Golkar at provincial and national level rather than between elite on Sumba. The strength of a bupati depended on his protection by superiors outside Sumba. His local popularity would be increased if during his term in office there would be ample funds from Jakarta flowing to Sumba, and if he would show the authority to settle large disputes in peace. Bupati Malo, Umbu Djima's successor in 1995, performed badly on all these fronts, being a mid-level colonel from the Air Force who had lived most of his life outside Sumba and who had a style 
of governing that was opposite of what Sumbanese traditionally prefer. He was bupati in 1998, when the economic and political crisis struck. Chapter VI described how he and his local rival, the chairman of the parliament and Golkar, turned ethnic identity into a political tool, when they invited kinsmen from their traditional domains to come to the capital for support. This was the first clear sign of a 180 degree turn in focus of the district government.

Having lost protection from the centre, bupati Malo turned to his local constituency in November 1998. But these constituencies were not altogether clear anymore. As Charles Tilly (2003:32) argued, political identities assemble four crucial elements: a. boundaries, separating 'us' from 'them' b. shared stories about those boundaries, c. social relations across the boundaries and d. social relations within the boundaries. These four issues composed the agenda of the movement to create a new district, as described in Chapter VIII. The movement's leaders had to create a new political identity for 'Central Sumbanese', encompassing four or five traditional geographic domains, but excluding the neighbouring domains, through stories that grounded in historical, cultural, religious or linguistic arguments.

During the democratic elections in 2004 and 2005, creation of political identity was the core activity for candidates trying to secure the largest constituency possible. In the case of elections, that identity should be inclusive, and therefore ethnicity in the sense of identification with traditional domains was not as explicitly important as in the case of creating a new district. The same politicians would now argue that marriage alliances with domains in the very west of Sumba legitimized the election candidates' leadership, whereas in pemekaran rhetoric the opposite would be the appropriate argument.

One of the conclusions in Chapter IX about the direct district-head elections, pilkada, in 2005, is that ethnicity and religion play an important role in the results of pilkada. All candidates, except one, won in their own home area, their traditional domain, but since there are many of these domains in West Sumba, a home victory is never sufficient to win the majority in the whole district. Election candidates therefore had to play out other political identities. The Catholic identity turned out to be an asset in an electorate that consisted of nearly 50 percent Catholics and in a field of competition where only two of the ten candidates adhered to this religion.

\section{Political class, political public and the tani class}

The developments on Sumba since 1998 can also be understood in terms of social classes. During the New Order, there was a fairly small elite of district state officials; and their connections with businesses were not openly acknowledged. Gradually since 1998, the local elite included a larger group 
that I call the political class. Those who are in the position to decide about the allocation of the state resources compose the political class, which includes the higher level executive currently in office, but also (some, not all) retired state officials, businessmen, political party bosses, clan leaders, religious leaders and the wives and mothers of all these influential men. Inclusion of (some) businessmen in the political class clearly distinguishes this concept from pegawai (state officials). Members of the political class are aware of their privileged position; they are very occupied with maintaining the relations within the class, and therefore create borders that restrict access to their class. There is no single institution that coincides with the political class; members connect with each other through networks that become visible at private ceremonial occasions and public meetings. Inclusion in the political class results in access to information, economic opportunities, state services (for example, police will actually act as they should when ordered by high police officials who are members of the political class) and it also provides the opportunity to skip the lower levels of bureaucracy (including the necessary bribes at those levels). The fact that the main criterion for membership of the political class is influence on the decision to allocate state resources (money, jobs, permits and violence) means that this membership has to be constantly reassured, and that downward mobility and losing influence can happen.

Feith (1962:108) used a political model and stratification that focused on the role of individuals in the political process, viewing them as participants in a leader-followers unit. This model sees the distribution of power beyond the elite as series of concentric circles, with power diminishing as one's political distance from the elite increases. The first circle surrounding the elite consists of people of lesser political influence. Feith (1962:109-10) calls them the 'political public', 'persons of a middle range of political effectiveness, persons outside the political elite who nevertheless saw themselves as capable of taking action which could affect national (district) government or politics'.

What Feith calls the masses, and in my terminology is the tani-class, is positioned in the outer circle, where people consider themselves of too low status to be politically active. There are no statistics about the size of these classes. I would estimate that at least two-thirds of Sumba's population considers themselves as common people with no influence on allocation of state resources. They make up the outer circle in Feith's model. The political public would include about a quarter of the population, leaving about 10per cent for the political class.

In this model the boundaries between the 'political class', the 'political public' and the 'tani' are not clearly delineated. Analytically this is a weakness of the concept of political class, and one of reason why according to Borchert (2002:3) some political or social scientists reject it. Yet, this fluidity between the classes is in accordance with reality, which makes the model empirically 
very useful. Exactly because the boundaries are not fixed, people in Sumba are so involved in accumulating various forms of capital in order to get access to the political class.

The political public and the 'tani' (those in the outer circles) benefit from a state that serves the public interest. This would be reflected in a high percentage of the state's budget being allocated to services for the public that are of high quality and without any additional political cost, fee or mark-up. But reality is different. The political class derives its livelihood from the state. They not only earn salaries as state officials, but also work as contractors by gaining state projects, as officials who can sell services for an additional fee, or who can issue permits in exchange for a percentage of the profit, or who can assemble votes in times of general elections. The higher one's position is, the better the chance of rewards.

The two sides in this cleavage are interdependent. The tani class is in control of food and land, labour and livestock, which are essential resources for all Sumbanese, whether urban or rural dwellers. The political class possesses money and access to opportunities for improving livelihood, through education and networks that stretch to the world outside Sumba. Politicians are usually already members of the political class, but they need the rural population as their constituency.

Violence in Waikabubak was a first sign of class conflict. 'Bloody Thursday' was not just another case of tribal war in West Sumba. Rethinking the local discourses and comparing it with the other cases described in literature, it appears that war between domains, perang suku, was always a powerful concept on Sumba, especially useful as a tool for mobilization. In November 1998, discourse about perang suku was used to divert a class conflict into a more manageable ethnic conflict. Bloody Thursday was the first case in West Sumba in which violence was directed at the state and those who appropriated its resources for the benefit of their small clique. The battle was fought in the streets of the district capital, state domain par excellence, as opposed to a plain somewhere between the groups' territories. The groups involved originally could be characterized as those in control of the state resources and those who lacked access to them. This cleavage in Sumbanese society is increasing and becoming the most important factor of social distinction. With increasing democratization, including fair and direct elections, it is not beneficial for the ruling elite to allow such a stark class divide. The old ethnic war model is much safer for their professional positions, turning them from leaders of the political class to leaders of ethnic groups that include many people who belong to the middle class or regard themselves as tani. 


\section{Democratization and Uma politics}

Have the changes in the national political context of Indonesia led to democratization in West Sumba? My conclusion at the end of this book is that there is positive change towards democracy. Diamond, Linz and Lipset (1995:6-7) described three essential conditions for democracy, based on their comparative research on experiences with democracy in a large number of developing countries: free and fair elections that exclude the use of force, a high level of political participation in the selection of leaders and policies, and civil and political liberties secured through political equality under a rule of law.

The elections in 2004 and 2005 were indeed free and fair. They were competitive and participatory, in the sense that everyone in Sumba knew at least some of the candidates for the district parliament elections; in June 2005, there were many discussions about the elections and large crowds visited the rallies. In West Sumba, 222,000 people were registered as voters, about 60 per cent of the total population. Writing about African elections, Staffan Lindberg (2006:150) argued that elections provide more than just an arena for political contestation. They sometimes give rise to new, independent institutions and often force political actors to adapt at least partly to voter preferences. In West Sumba, all election candidates had to address the voters directly, which in itself was a democratic achievement. Apart from the elections, there was no wide participation in the selection of leaders. Political party boards eventually decided who would be the candidates on the election list and their ranking. In the parliament elections this procedure led to voters' disappointment when they found out that a popular candidate was not elected because of low ranking. National Political party board's priorities caused the incumbent bupati of West Sumba to lose his PDI-P candidacy to a wealthy Jakarta based politician.

Civil and political liberties have increased enormously since 1998. There are frequent demonstrations and press can print critical commentaries on current events. The fact that in October 1998 there was a popular uprising in Waikabubak focused on issues of governmental corruption buttressed the case for democratic reforms and fairer elections (as well as fairer civil service examinations), although it was of course tragic that those demonstrations led to mass violence.

A real democracy can only function effectively if the citizens are participating. Civil society has been the common term to describe this since the late 1980s, when people in NGOs and political parties started their discourse on 'strengthening civil society' (Wolters 2002:132). I prefer to call the participating citizens the 'political public', because this term does not have an a priori normative content. The political public can vote in elections, can organize themselves to promote the group's interests using the democratic means, but 
they can also resort to violence or create a secession movement. That intermediate class could only emerge after preconditions of access to media (information), freedom of speech and freedom to assemble were established. What determines membership of this political public is the state of mind which requires a man to communicate with other people than those to whom he is tied within his traditional society' (Feith 1962:110). As an increasing part of the Sumbanese population received access to electricity, everywhere people started watching television. Communications with other areas in Indonesia became easier since cell phones have become available on Sumba. Many young people went to study on Java or in Kupang, and since not all of them succeeded finding employment elsewhere, a considerable group returned to Sumba. They did not want to become farmers, but they were more ambitious and preferred a position as civil servants. Regional autonomy and direct elections involved people in politics. The political public has been growing since 1998, and that is also an achievement of democratization.

What Diamond, Linz and Lipset's criteria of democracy do not catch is how local leaders in Sumba use the opportunities created by changes in the national political context in Indonesia to farther their own interest and stay in power. The growth of the political class with its exclusive and privileged character overshadows the positive aspects of democratization. Travelling along the main road from Anakalang to Waikabubak, it is striking to see how many new fancy houses were built over the last two years and how many huge offices and churches emerged. In the same period there was not much change for the tani class. Regional autonomy seems to have increased the inequality in wealth between political class and the tani class. For some developments, it is too early to judge what may happen. The effect of creating a new district will only be clear after it has been established for some years. The cost of the campaign was accumulated from 2003 to 2006 when a large amount of economic capital was transferred either to the local political class or to brokers and gate keepers in Jakarta and Kupang as bribes in the process to move the decision through all political institutions.

The test of democratic achievements will come after the elections. If state services follow through with the promises made in election speeches and benefit the population in their interests, the achievements will be positive. Yet, when we look closely at the local politics, there is ample reason for concern. The bupati and DPRD members are completely entangled in reciprocal obligations which became clear after the elections. The political campaigns were financed by businessmen (tim sukses). Politicians gathered their constituencies by mobilising social networks and depending on the cooperation of people who occupied crucial knots in those networks. The latter, too, will demand reciprocal services, in positions, jobs or other types of rewards. Actors 
in the political class are intimately linked to each other within this reciprocal economy centred on state resources, as if they were brothers in an Uma. If I refer to present day politics in Sumba as 'Uma politics', it is not in reference to the kinship based traditional Uma. However, the political reciprocal system is quite reminiscent of the ties within an Uma. There is a large chance that Uma politics of the political class, especially those concentrated in circles around the bupati, can best be understood as a black economy, in which 'reciprocal services' are a euphemism for diverting government funds into private pockets. The many new, fancy houses in Sumba's two capital towns are a sign of black economy benefits, because salaries of the owners could never pay for such houses built at that pace. The highest members of the political class, such as, the high level bureaucrats, politicians and businessmen, invest the wealth they gather on Sumba outside the island. Their children pursue their education abroad, they buy land in other parts of Indonesia, or build their luxury houses in Jakarta or Surabaya. These developments are a challenge for further research, which is required to supply arguments to the tiny opposition in Sumba in their struggle to remind the government of the fundamental claim that it is a public body working on behalf of the people. 